\title{
Melitea salexigens gen. nov., sp. nov., a gammaproteobacterium from the Mediterranean Sea
}

Correspondence

Philippe Lebaron

lebaron@obs-banyuls.fr

\author{
Laurent Urios, ${ }^{1,2}$ Hélène Agogué, ${ }^{1,2}$ Laurent Intertaglia, ${ }^{1,2}$ \\ Françoise Lesongeur ${ }^{3}$ and Philippe Lebaron ${ }^{1,2}$
}

\author{
${ }^{1}$ Université Pierre et Marie Curie - Paris 6, Laboratoire ARAGO, Avenue du Fontaulé, BP 44, F- \\ 66650 Banyuls-sur-Mer, France \\ ${ }^{2}$ CNRS, UMR7621, Laboratoire d'Océanographie Biologique de Banyuls, Avenue du Fontaulé, BP \\ 44, F-66650 Banyuls-sur-Mer, France \\ ${ }^{3}$ Laboratoire de Microbiologie des Environnements Extrêmes, UMR 6197, IFREMER, Centre de \\ Brest, BP 70, F-29280 Plouzané, France
}

The genus Microbulbifer was originally proposed by Gonzales et al. (1997) and at the time of writing includes five species: Microbulbifer hydrolyticus (Gonzalez et al., 1997), M. salipaludis (Yoon et al., 2003a), M. maritimus (Yoon et al., 2004), M. elongatus (Humm, 1946; Palleroni, 1984; Yoon et al., 2003b) and M. celer (Yoon et al., 2007). Chemical markers for this genus include the presence of iso$15: 0$ and iso- $17: 1 \omega 9 c$ as major fatty acids and Q-8 as the major ubiquinone (Yoon et al., 2004). Microbulbifer species have been isolated from various marine environments, including salt marshes, intertidal sediments and coastal waters. As part of a larger survey of the diversity of the seawater surface microlayer (Agogue et al., 2004), several novel marine bacteria were discovered and described, including Haliea salexigens $3 \mathrm{X} / \mathrm{A} 02 / 235^{\mathrm{T}}$ (Urios et al., 2008) and an uncharacterized strain, designated 5IX/A01/ 131. Both of these strains are related to the genus Microbulbifer but, on the basis of $16 \mathrm{~S}$ rRNA gene sequences and fatty acid compositions, are distinct taxonomically. The taxonomy of strain 5IX/A01/131 is defined in this study, leading to the proposal of a novel marine genus and species.

The GenBank/EMBL/DDBJ accession number for the 16S rRNA gene sequence of strain $5 I X / A 01 / 131^{\top}$ is AY576729.

An electron micrograph of a negatively stained cell of $5 \mathrm{IX} / \mathrm{A} 01 / 131^{\top}$ and graphs showing the effects of $\mathrm{pH}$, salinity and temperature on growth are available as supplementary material with the online version of this paper.
Samples of seawater from the surface microlayer were collected in September 2001 from the bay of Barcelona $\left(41^{\circ}\right.$ $24^{\prime} \mathrm{N} 2^{\circ} 16^{\prime} \mathrm{E}$ ) by submerging a metal screen (Agogué et al., 2004). Subsamples were spread on MA plates and incubated at $25{ }^{\circ} \mathrm{C}$ for 2 weeks. Colonies were picked and purified after three subcultures. An isolate that formed cream-coloured colonies was obtained from among these colonies and was designated strain 5IX/A01/131 ${ }^{\mathrm{T}}$ (Agogué et al., 2005).

Microscopic observations (AX70; Olympus) showed that cells from isolate $5 \mathrm{IX} / \mathrm{A} 01 / 131^{\mathrm{T}}$ were motile rods, approximately $1.8 \pm 0.2 \mu \mathrm{m}$ long and $0.7 \pm 0.1 \mu \mathrm{m}$ wide. Cells were negatively stained for transmission electron microscopy (Raguénès et al., 1997). Single polar flagella were observed (Supplementary Fig. S1, available in IJSEM Online) and the Ryu KOH reaction (Powers, 1995) led to immediate cell lysis that was confirmed by microscopy. This positive reaction indicated that the strain was Gram-negative.

The isolate was grown in marine broth 2216 medium (MB; Difco). To determine the range of salinities tolerated by strain $5 \mathrm{IX} / \mathrm{A} 01 / 131^{\mathrm{T}}, \mathrm{MB}$ was prepared according to the composition provided by the manufacturer, with the appropriate $\mathrm{NaCl}$ concentration. To test the $\mathrm{pH}$ range for growth, MES, PIPES, AMPSO or MOPS (Sigma) was added to $\mathrm{MB}$ to achieve the appropriate $\mathrm{pH}$. Cultures were incubated at $30{ }^{\circ} \mathrm{C}$ under aerobic conditions. The methods 
Table 1. Characteristics that serve to distinguish strain $5 I X / A 01 / 131^{\top}$ from the type strains of related species

Strains: 1, M. maritimus JCM $12187^{\mathrm{T}}$ (data from Yoon et al., 2004); 2, M. hydrolyticus DSM $11525^{\mathrm{T}}$ (Gonzalez et al., 1997); 3, M. salipaludis KCCM $41586^{\mathrm{T}}$ (Yoon et al., 2003a); 4, M. elongatus DSM 6810 ${ }^{\mathrm{T}}$ (Yoon et al., 2003b); 5, M. celer KCTC $12973^{\mathrm{T}}$ (Yoon et al., 2007); 6, H. salexigens OOB $286^{\mathrm{T}}$ (Urios et al., 2008); 7, strain 5IX/A01/131 ${ }^{\mathrm{T}}$. All strains were positive for the following characteristics: alkaline phosphatase, leucine arylamidase, acid phosphatase and naphthol-AS-BI-phosphohydrolase. All strains possessed Q-8 as the major quinone. +, Positive; -, negative; $(+)$, weakly positive; ND, no data available.

\begin{tabular}{|c|c|c|c|c|c|c|c|}
\hline Characteristic & 1 & 2 & 3 & 4 & 5 & 6 & 7 \\
\hline Sampling environment & Marine sediment & Salt marsh & Salt marsh & Sand and seawater & Marine saltern & Seawater & Seawater \\
\hline DNA G $+\mathrm{C}$ content $(\mathrm{mol} \%)$ & 59.9 & 57.7 & 59 & 58.2 & 57.7 & 61.4 & 57.2 \\
\hline Motility & - & - & - & + & - & + & + \\
\hline \multicolumn{8}{|l|}{ Temperature for growth $\left({ }^{\circ} \mathrm{C}\right)$} \\
\hline Range & $15-48$ & $10-41$ & $10-45$ & $25-30$ & $10-48$ & $10-37$ & $15-37$ \\
\hline Optimum & 37 & 37 & 37 & $25-30$ & 37 & 25 & 30 \\
\hline \multicolumn{8}{|l|}{ Salinity for growth $\left(\mathrm{g} \mathrm{NaCl}^{-1}\right)$} \\
\hline Range & $2-10$ & $6-60$ & $2-10$ & ND & ND & $7-70$ & $7-70$ \\
\hline Optimum & $2-4$ & $6-30$ & $2-3$ & $2-3$ & ND & 42 & 28 \\
\hline \multicolumn{8}{|l|}{$\mathrm{pH}$ for growth } \\
\hline Range & $5-7.5$ & $6.5-8.5$ & $5-8$ & $\mathrm{ND}$ & $5-8$ & $5-9$ & $6-10$ \\
\hline Optimum & $6.5-7.5$ & 7.5 & $7-8$ & $\mathrm{ND}$ & $7-8$ & 8 & 8 \\
\hline \multicolumn{8}{|l|}{ API ZYM tests } \\
\hline Valine arylamidase & - & - & - & - & - & + & - \\
\hline$N$-Acetyl- $\beta$-glucosaminidase & - & - & + & + & + & - & $(+)$ \\
\hline Esterase $(\mathrm{C} 4)$ & + & + & + & + & + & - & - \\
\hline Lipase (C8) & + & + & + & + & + & $(+)$ & $(+)$ \\
\hline \multicolumn{8}{|l|}{ Substrates } \\
\hline Arabinose & - & + & - & + & + & - & - \\
\hline Cellobiose & + & + & + & + & - & - & $(+)$ \\
\hline Fructose & - & - & - & + & - & - & + \\
\hline Galactose & - & - & - & + & - & - & - \\
\hline Glucose & + & + & + & + & - & - & + \\
\hline Lactose & - & - & - & + & + & - & $(+)$ \\
\hline Maltose & + & + & + & + & - & - & + \\
\hline Mannose & - & - & - & + & - & $(+)$ & + \\
\hline Rhamnose & - & - & + & - & - & - & - \\
\hline Raffinose & - & $\mathrm{ND}$ & - & - & - & - & + \\
\hline Sucrose & - & - & - & + & - & - & + \\
\hline Glycerol & $\mathrm{ND}$ & - & ND & - & ND & + & - \\
\hline Acetate & + & + & $\mathrm{ND}$ & + & + & - & $(+)$ \\
\hline Aspartate & $\mathrm{ND}$ & - & $\mathrm{ND}$ & $(+)$ & ND & + & - \\
\hline Glutamate & - & + & $\mathrm{ND}$ & + & - & $(+)$ & $(+)$ \\
\hline$\beta$-Hydroxybutyrate & $\mathrm{ND}$ & + & $\mathrm{ND}$ & $\mathrm{ND}$ & ND & + & - \\
\hline Lactate & - & $\mathrm{ND}$ & $\mathrm{ND}$ & + & $\mathrm{ND}$ & - & - \\
\hline Propionate & $\mathrm{ND}$ & + & $\mathrm{ND}$ & + & $\mathrm{ND}$ & - & - \\
\hline Pyruvate & + & + & $\mathrm{ND}$ & $\mathrm{ND}$ & + & + & - \\
\hline Succinate & + & + & $\mathrm{ND}$ & + & - & + & - \\
\hline Alanine & $\mathrm{ND}$ & + & $\mathrm{ND}$ & $(+)$ & $\mathrm{ND}$ & - & $(+)$ \\
\hline Leucine & $\mathrm{ND}$ & + & ND & + & $\mathrm{ND}$ & + & - \\
\hline Proline & $\mathrm{ND}$ & + & $\mathrm{ND}$ & $(+)$ & $\mathrm{ND}$ & + & - \\
\hline Serine & + & + & ND & - & ND & - & - \\
\hline Tween 80 & $\mathrm{ND}$ & - & + & ND & + & + & - \\
\hline
\end{tabular}

used for the determination of growth parameters were as reported by Wery et al. (2001b). Growth was observed at 15$37{ }^{\circ} \mathrm{C}$, with a clear optimum at $30{ }^{\circ} \mathrm{C}$ (Supplementary Fig. S2). The strain grew at $\mathrm{NaCl}$ concentrations ranging from 7 to $70 \mathrm{~g} \mathrm{l}^{-1}$ and an optimum concentration could be defined as $42 \mathrm{~g} \mathrm{l}^{-1}$ (Supplementary Fig. S2). Growth occurred at
$\mathrm{pH}$ 6.0-10.0, with an optimum at $\mathrm{pH}$ 8.0. Growth decreased by $49 \%$ at $\mathrm{pH} 6.0$ in comparison with the value obtained at $\mathrm{pH}$ 7.0. Growth rates were the same at $\mathrm{pH} 7.0$ and $\mathrm{pH} 9.0$; a small difference $(14 \%)$ was observed between $\mathrm{pH} 9.0$ and 10.0 (Supplementary Fig. S2). To investigate the possibility of growth under anaerobic conditions, cultures were placed in 


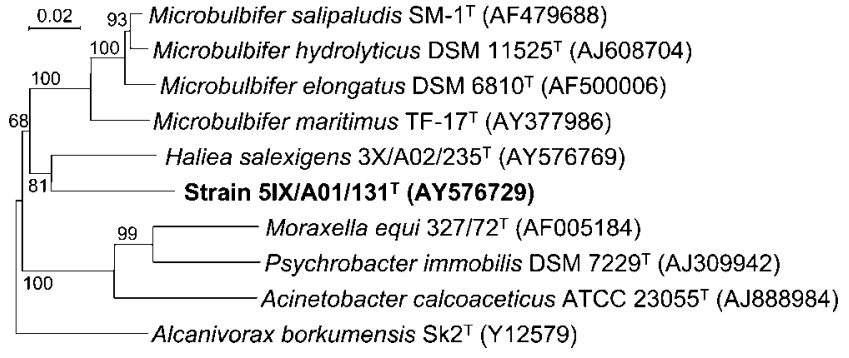

Fig. 1. Phylogenetic tree, based on $16 \mathrm{~S}$ rRNA gene sequences, showing the position of strain $5 \mathrm{IX} / \mathrm{A} 01 / 131^{\top}$. The tree corresponds to an unrooted tree obtained using the neighbour-joining algorithm (with Kimura corrections). Accession numbers and type strains are indicated. Bootstrap percentages (based on 1000 resamplings) are shown at branch points. Bar, 0.02 substitutions per nucleotide position.

an anaerobic jar on MA plates at optimal conditions of temperature, $\mathrm{pH}$ and salinity (Supplementary Fig. S2). No growth was observed after 10 days and thus the strain should be considered as strictly aerobic.

The ability of isolate $5 \mathrm{IX} / \mathrm{A} 01 / 131^{\mathrm{T}}$ to use various substrates was investigated using Biolog GN2 MicroPlates (Tang et al., 1998) according to the manufacturer's instructions. Positive reactions are listed in the species description. A comparison between strain 5IX/A01/131 ${ }^{\mathrm{T}}$ and its closest relatives is presented in Table 1.

Enzyme activities were investigated using the API ZYM system (bioMérieux) according to the manufacturer's instructions. Positive reactions were obtained for alkaline phosphatase, leucine arylamidase, acid phosphatase and naphthol-AS-BI-phosphohydrolase. Weakly positive signals were obtained for esterase (C8) and $\mathrm{N}$-acetylglucosaminidase (Table 1).

Analysis of the fatty acid methyl esters was performed by the Identification Service of the Deutsche Sammlung von Mikroorganismen und Zellkulturen (DSMZ, Braunschweig, Germany). To allow comparisons between the fatty acid composition of strain $5 \mathrm{IX} / \mathrm{A} 01 / 131^{\mathrm{T}}$ and those of its relatives, MA was used. Biomass was harvested from MA plates after cultivation at optimal conditions (Supplementary Fig. S2). The fatty acid composition (\%) for isolate 5IX/A01/131 ${ }^{\mathrm{T}}$ was as follows: $17: 1 \omega 8 c(34.1), 17: 0$ (13.0), $18: 1 \omega 7 c$ (11.4), $16: 1 \omega 7 c /$ iso- $15: 0 \quad 2-\mathrm{OH}$ (9.0), $15: 0$ (5.3), $11: 03-\mathrm{OH}$ (4.6), iso-11:0 $3-\mathrm{OH}$ (4.3), $16: 0$ (3.9), iso-15:0 (2.0), 9:0 (1.9), $10: 03-\mathrm{OH}$ (1.7), iso- $17: 0$ (1.3), iso-13:0 (1.0), iso-11:0 (0.9), 14:0(0.8), 11:0 (0.7), $17: 1 \omega 6 c(0.6), 18: 0(0.5), 12: 13-\mathrm{OH}(0.5), 13: 0$ (0.4), $12: 0(0.3)$ and 9:0 3-OH (0.3). Fatty acids $9: 0$, iso$13: 0,9: 03-\mathrm{OH}$ and $12: 13-\mathrm{OH}$ were only detected in strain $5 \mathrm{IX} / \mathrm{A} 01 / 131^{\mathrm{T}}$. Fatty acids $11: 0,12: 0,13: 0$, $17: 1 \omega 6 c$ and $11: 03-\mathrm{OH}$ were found in strains 5IX/A01/ $131^{\mathrm{T}}$ and $H$. salexigens DSM $19537^{\mathrm{T}}$ but not in Microbulbifer species. Fatty acids iso-11:0, iso-15:0 and
Table 2. Cellular fatty acid compositions (\%) of strain $5 \mathrm{IX/}$ $\mathrm{A} 01 / 131^{\top}$ and related type strains in the genus Microbulbifer

Strains: 1, M. maritimus JCM $12187^{\mathrm{T}}$ (data from Yoon et al., 2004); 2 , M. hydrolyticus DSM $11525^{\mathrm{T}}$ (Gonzalez et al., 1997); 3, M. salipaludis KCCM $41586^{\mathrm{T}}$ (Yoon et al., 2003a); 4, M. elongatus DSM $6810^{\mathrm{T}}$ (Yoon et al., 2003b); 5, M. celer KCTC $12973^{\mathrm{T}}$ (Yoon et al., 2007); 6, H. salexigens OOB $286^{\mathrm{T}}$ (Urios et al., 2008); 7 , strain $5 \mathrm{IX} / \mathrm{A} 01 / 131^{\mathrm{T}}$. - , Not detected/not reported.

\begin{tabular}{|c|c|c|c|c|c|c|c|}
\hline Fatty acid & 1 & 2 & 3 & 4 & 5 & 6 & 7 \\
\hline $9: 0$ & - & - & - & - & - & - & 1.9 \\
\hline $10: 0$ & 1.3 & 1.7 & 2.4 & 1.6 & 1.6 & - & - \\
\hline $11: 0$ & - & - & - & - & - & 1.0 & 0.7 \\
\hline $12: 0$ & - & - & - & - & - & 1.6 & 0.3 \\
\hline $13: 0$ & - & - & - & - & - & 1.3 & 0.4 \\
\hline $14: 0$ & 1.0 & 1.2 & 2.6 & 0.7 & 0.9 & 1.3 & 0.8 \\
\hline $15: 0$ & 1.6 & 1.5 & 1.7 & 0.9 & 1.5 & 4.5 & 5.3 \\
\hline $16: 0$ & 8.7 & 11.4 & 16.3 & 7.1 & 12.6 & 2.0 & 3.9 \\
\hline $17: 0$ & 1.3 & 2.9 & 2.2 & 2.5 & 2.6 & 9.3 & 13.0 \\
\hline $18: 0$ & - & 1.6 & 1.4 & 1.2 & 0.8 & - & 0.5 \\
\hline 17:0 cyclo & 2.3 & 5.7 & - & - & 6.3 & - & - \\
\hline $19: 0 \omega 8 c$ cyclo & 1.4 & 1.0 & - & - & 5.3 & - & - \\
\hline iso- $11: 0$ & 10.0 & 5.7 & 4.8 & 6.5 & 6.7 & - & 0.9 \\
\hline iso- $13: 0$ & - & - & - & - & - & - & 1.0 \\
\hline iso- $15: 0$ & 25.9 & 24.4 & 19.4 & 20.7 & 21.7 & - & 2.0 \\
\hline iso- $15: 1$ & 0.8 & 1.0 & 0.7 & 1.0 & 0.4 & - & - \\
\hline iso- $16: 0$ & - & - & - & 0.5 & 0.3 & - & - \\
\hline iso- $17: 0$ & 6.9 & 10.4 & 5.5 & 9.9 & 10.0 & - & 1.3 \\
\hline anteiso-17:0 & - & - & - & 0.8 & 0.3 & - & - \\
\hline iso- $17: 1 \omega 9 c$ & 12.6 & 10.1 & 9.5 & 11.3 & 8.6 & - & - \\
\hline $15: 1 \omega 6 c$ & - & - & - & - & - & 5.8 & - \\
\hline $17: 1 \omega 6 c$ & - & - & - & - & - & 2.7 & 0.6 \\
\hline $17: 1 \omega 8 c$ & - & 0.5 & 1.0 & 1.8 & 0.5 & 23.9 & 34.1 \\
\hline $18: 1 \omega 5 c$ & - & - & 0.7 & - & - & - & - \\
\hline $18: 1 \omega 7 c$ & 5.6 & 8.9 & 11.8 & 16.3 & 6.5 & 17.5 & 11.4 \\
\hline $9: 03-\mathrm{OH}$ & - & - & - & - & - & - & 0.3 \\
\hline $10: 03-\mathrm{OH}$ & 1.7 & 1.0 & 1.2 & 1.6 & 1.4 & 1.8 & 1.7 \\
\hline $11: 03-\mathrm{OH}$ & - & - & - & - & - & 3.3 & 4.6 \\
\hline $12: 03-\mathrm{OH}$ & - & - & - & - & - & 1.1 & - \\
\hline $12: 13-\mathrm{OH}$ & - & - & - & - & - & - & 0.5 \\
\hline $16: 02-\mathrm{OH}$ & - & - & 0.9 & - & - & - & - \\
\hline iso-11:0 $3-\mathrm{OH}$ & 14.2 & 6.2 & 5.7 & 7.7 & 8.9 & 3.3 & 4.3 \\
\hline iso-17:0 $3-\mathrm{OH}$ & - & - & 0.9 & - & - & - & - \\
\hline $\begin{array}{c}16: 1 \omega 7 c / \text { iso- } \\
15: 02-\mathrm{OH}\end{array}$ & 2.2 & 2.7 & 7.1 & 6.0 & 2.4 & 21.2 & 9.0 \\
\hline
\end{tabular}

iso-17:0 were found in strain $5 \mathrm{IX} / \mathrm{A} 01 / 131^{\mathrm{T}}$ and in Microbulbifer species but not in $H$. salexigens DSM $19537^{\mathrm{T}}$. The major fatty acid found in all Microbulbifer strains, iso-15:0, was 10-fold less abundant in strain 5IX/ $\mathrm{A} 01 / 131^{\mathrm{T}}$ and iso-17: $1 \omega 9 c$, one of the other major fatty acids of Microbulbifer strains, was not detected in the novel strain. Fatty acids 12:0 $3-\mathrm{OH}$ and 15:1 $1 \omega 6 c$, one of the most abundant fatty acids in $H$. salexigens DSM $19537^{\mathrm{T}}$, were not found in strain 5IX/A01/131 ${ }^{\mathrm{T}}$.

Analyses of respiratory quinones and polar lipids were carried out by the Identification Service of the DSMZ. 
Strain 5IX/A01/131 ${ }^{\mathrm{T}}$ contained Q-8 and the major polar lipids were diphosphatidylglycerol, phosphatidylglycerol and an undefined aminophospholipid.

Genomic DNA was extracted as described by Wery et al. (2001a). The G $+C$ content was determined by means of thermal denaturation, using the method of Marmur \& Doty (1962) and the conditions described by Raguénès et al. (1997). The $\mathrm{G}+\mathrm{C}$ content of the genomic DNA of strain $5 \mathrm{IX} / \mathrm{A} 01 / 131^{\mathrm{T}}$ was $57.2 \pm 0.2 \mathrm{~mol} \%$. The $16 \mathrm{~S}$ rRNA gene was amplified and sequenced as described by Agogué et al. (2005). The sequence was analysed as described by Urios et al. (2006). Strain 5IX/A01/131 ${ }^{\mathrm{T}}$ was shown to be phylogenetically affiliated to the family Alteromonadaceae in the class Gammaproteobacteria (Fig. 1). The closest relative was $H$. salexigens $3 \mathrm{X} / \mathrm{A} 02 / 235^{\mathrm{T}}$, with a sequence similarity of $91 \%$.

Differences in several phenotypic properties, as shown in Tables 1 and 2, serve to distinguish strain 5IX/A01/131 ${ }^{\mathrm{T}}$ from its closest phylogenetic relatives. On the basis of these differences, we propose that strain $5 \mathrm{IX} / \mathrm{A} 01 / 131^{\mathrm{T}}$ should be assigned to a novel species and genus. Because of the marine origin of strain $5 \mathrm{IX} / \mathrm{A} 01 / 131^{\mathrm{T}}$ and its salinity requirement, the name Melitea salexigens gen. nov., sp. nov. is proposed.

\section{Description of Melitea gen. nov.}

Melitea (Me.li'te.a. N.L. fem. n. Melitea named after Melite, a nymph of the sea in Greek mythology, referring to the marine origin).

Cells are motile, Gram-negative rods. The major fatty acids are $17: 1 \omega 8 c, 17: 0,18: 1 \omega 7 c, 16: 1 \omega 7 c, 15: 0,11: 03-\mathrm{OH}$, iso- $11: 03-\mathrm{OH}, 16: 0$, iso- $15: 0,9: 0,10: 03-\mathrm{OH}$, iso- $17: 0$ and iso-13:0. The ubiquinone is Q-8 and the polar lipids are diphosphatidylglycerol and phosphatidylglycerol. Phylogenetically affiliated to the class Gammaproteobacteria. The type species is Melitea salexigens.

\section{Description of Melitea salexigens sp. nov.}

Melitea salexigens (sa.le'xi.gens. L. n. sal, salis salt, seawater; L. v. exigo to demand; N.L. part. adj. salexigens seawaterdemanding).

Displays the following properties in addition to those described for the genus. Cream colonies are formed on MA medium. Cells are $1.8 \pm 0.2 \mu \mathrm{m}$ long and $0.7 \pm 0.1 \mu \mathrm{m}$ wide with single polar flagella. The DNA $\mathrm{G}+\mathrm{C}$ content of the type strain is $57 \mathrm{~mol} \%$. Growth occurs at $15-37{ }^{\circ} \mathrm{C}$ (optimally at $30^{\circ} \mathrm{C}$ ), at $\mathrm{pH} 6.0-10.0$ (optimally at $\mathrm{pH} 8.0)$ and at salinities in the range $7-70 \mathrm{~g} \mathrm{NaCl}^{-1}$ (optimally at $42 \mathrm{~g}^{-1}$ ). Positive reactions with Biolog GN2 plates are obtained for D-fructose, D-glucose, maltose, Dmannose, D-psicose, raffinose, sucrose, trehalose, turanose, $\alpha$-ketoglutaric acid, $\alpha$-ketovaleric acid, succinamic acid, Lglutamic acid and L-serine. Positive API ZYM reactions for enzyme activities are obtained for alkaline phosphatase, leucine arylamidase, acid phosphatase and naphthol-ASBI-phosphohydrolase. Oxidase- and catalase-positive.

The type strain, 5IX/A01/131 ${ }^{\mathrm{T}}\left(=\mathrm{DSM} 19753^{\mathrm{T}}=\mathrm{CIP}\right.$ $109757^{\mathrm{T}}=$ MOLA $225^{\mathrm{T}}$ ), was isolated from seawater sampled from the surface microlayer in the bay of Barcelona $\left(41^{\circ} 24^{\prime} \mathrm{N} 2^{\circ} 16^{\prime} \mathrm{E}\right)$.

\section{Acknowledgements}

This work was supported by the Equipe Mixte de Recherche linking the Université Pierre et Marie Curie and the Centre National de la Recherche Scientifique to the Pierre Fabre Laboratories. The project was also carried out within the framework of the MarBEF Network of Excellence 'Marine Biodiversity and Ecosystem Functioning', which is funded within the Community's Sixth Framework Programme (contract no. GOCE-CT-2003-505446). This publication is contribution number MPS-07066 of MarBEF. It was also partly funded by the French programme 'Bio-diversité et Changement Global project: development of a coastal microbial observatory' from the Institut Français de la Biodiversité (IFB-GICC, Paris, France).

\section{References}

Agogué, H., Casamayor, E. O., Joux, F., Obernosterer, I., Dupuy, C., Lantoine, F., Catala, P., Weinbauer, M. G., Reinthaler, T. \& other authors (2004). Comparison of samplers for the biological characterization of the sea surface microlayer. Limnol Oceanogr Methods 2, 213-225.

Agogué, H., Casamayor, E. O., Bourrain, M., Obernosterer, I., Joux, F., Herndl, G. J. \& Lebaron, P. (2005). A survey on bacteria inhabiting the sea surface microlayer of coastal ecosystems. FEMS Microbiol Ecol 54, 269-280.

Gonzalez, J. M., Mayer, F., Moran, M. A., Hodson, R. E. \& Whitman, W. B. (1997). Microbulbifer hydrolyticus gen. nov., sp. nov., and Marinobacterium georgiense gen. nov., sp. nov., two marine bacteria from a lignin-rich pulp mill waste enrichment community. Int J Syst Bacteriol 47, 369-376.

Humm, H. J. (1946). Marine agar-digesting bacteria of the South Atlantic coast. Duke Univ Mar Stn Bull 3, 45-75.

Marmur, J. \& Doty, P. (1962). Determination of the base composition of deoxyribonucleic acid from its thermal denaturation temperature. $J$ Mol Biol 5, 109-118.

Palleroni, N. J. (1984). Genus Pseudomonas Migula 1894. In Bergey's Manual of Systematic Bacteriology, vol. 1, pp. 141-199. Edited by N. R. Krieg \& J. G. Holt. Baltimore: Williams \& Wilkins.

Powers, E. M. (1995). Efficacy of the Ryu nonstaining $\mathrm{KOH}$ technique for rapidly determining Gram reactions of food-borne and waterborne bacteria and yeasts. Appl Environ Microbiol 61, 3756-3758.

Raguénès, G., Christen, R., Guézennec, J., Pignet, P. \& Barbier, G. (1997). Vibrio diabolicus sp. nov., a new polysaccharide-secreting organism isolated from a deep-sea hydrothermal vent polychete annelid, Alvinella pompejana. Int J Syst Bacteriol 47, 989-995.

Tang, Y. W., Ellis, N. M., Hopkins, M. K., Smith, D. H., Dodge, D. E. \& Persing, D. H. (1998). Comparison of phenotypic and genotypic techniques for identification of unusual aerobic pathogenic gramnegative bacilli. J Clin Microbiol 36, 3674-3679.

Urios, L., Agogué, H., Lesongeur, F., Stackebrandt, E. \& Lebaron, P. (2006). Balneola vulgaris gen. nov., sp. nov., a member of the phylum Bacteroidetes from the north-western Mediterranean Sea. Int J Syst Evol Microbiol 56, 1883-1887. 
Urios, L., Intertaglia, L., Lesongeur, F. \& Lebaron, P. (2008). Haliea salexigens gen. nov., sp. nov., a member of the Gammaproteobacteria from the Mediterranean Sea. Int J Syst Evol Microbiol 58, 1233-1237.

Wery, N., Lesongeur, F., Pignet, P., Derennes, V., Cambon-Bonavita, M.-A., Godfroy, A. \& Barbier, G. (2001a). Marinitoga camini gen. nov., sp. nov., a rod-shaped bacterium belonging to the order Thermotogales, isolated from a deep-sea hydrothermal vent. Int $J$ Syst Evol Microbiol 51, 495-504.

Wery, N., Moricet, J., Cueff, V., Jean, J., Pignet, P., Lesongeur, F., Cambon-Bonavita, M.-A. \& Barbier, G. (2001b). Caloranaerobacter azorensis gen. nov., sp. nov., an anaerobic thermophilic bacterium isolated from a deep-sea hydrothermal vent. Int J Syst Evol Microbiol 51, 1789-1796.
Yoon, J. H., Kim, I. G., Shin, D. Y., Kang, K. H. \& Park, Y. H. (2003a). Microbulbifer salipaludis sp. nov., a moderate halophile isolated from a Korean salt marsh. Int J Syst Evol Microbiol 53, 53-57.

Yoon, J. H., Kim, I. G., Kang, K. H., Oh, T. K. \& Park, Y. H. (2003b). Transfer of Pseudomonas elongata Humm 1946 to the genus Microbulbifer as Microbulbifer elongatus comb. nov. Int J Syst Evol Microbiol 53, 1357-1361.

Yoon, J. H., Kim, I. G., Oh, T. K. \& Park, Y. H. (2004). Microbulbifer maritimus sp. nov., isolated from an intertidal sediment from the Yellow Sea, Korea. Int J Syst Evol Microbiol 54, 1111-1116.

Yoon, J. H., Jung, S. Y., Kang, S. J. \& Oh, T. K. (2007). Microbulbifer celer sp. nov., isolated from a marine solar saltern of the Yellow Sea in Korea. Int J Syst Evol Microbiol 57, 2365-2369. 